\title{
ANALISIS DAN KONSEP PERENCANAAN KAWASAN PELABUHAN KOTA PENAJAM SEBAGAI PINTU GERBANG KAB. PENAJAM PASER UTARA KALIMANTAN TIMUR
}

\author{
Amiruddin Akbar Fisu ${ }^{1}$ \\ ${ }^{1}$ Dosen Program Studi Teknik Sipil Universitas Andi Djemma Palopo \\ amiruddinakbarfisu07@ gmail.com
}

\begin{abstract}
Abstrak
Kawasan Pelabuhan sebagai pintu gerbang untuk masuk dan keluar dan Kabupaten Penajam Paser Utara memiliki nilai yang cukup strategis sehingga pengembangan dan pemanfaatan ruang kawasan tersebut harusnya memberi nilai Iebih bagi masyarakat Kabupaten Penajam. Sebagai jalur lintasan trans Kalimantan, kawasan Pelabuhan Penajam memiliki peran penting dalam sirkulasi pergerakan penduduk dan barang balk antar kota dalam wilayah propinsi Kalimantan Timur atau antar kota yang memiliki kedekatan fisik wilayah, sehingga kawasan tersebut menjadi entri point bagi Kabupaten Penajam Paser Utara. Namun penataan kawasan mi belumlah optimal, hal mi dikarenakan keberadaan kawasan pemukiman atas air yang terkesan kumuh dan tidak sehat. Permasalahan lain adalah kurangnya ruang publik di Penajam juga menjadi salahsatu masalah tersendiri. Selain itu, masyarakat Penajam tidak memiliki onientasi yang jelas juga tidak mengenali identitas yang jelas terhadap suatu tempat dan keselarasan hubungan dengan tempat- tempat lain di Kota Penajam. Perencanaan mi dilakukan dengan beberapa kajian pustaka sebagai landasan untuk merencanakan kawasan pelabuhan yang dimaksud serta landasan-landasan untuk pembuatan konsep. Analisis yang digunakan dalam perencanaan mi adalah analisis potensi dan masalah, analisis karakteristik pantai, analisis kebutuhan ruang public, Analisis citra kawasan, analisis kelayakan pelabuhan, Analisis kebutuhan lahan parkmr, analisis jumlah penumpang dan kendaraan pelabuhan ferry, dan analisis kelayakan permukiman kumuh. Output utama dalam perencanaan ini adalah konsep penataan pelabuhan, perencanaan ruang publik (public space), dan penataan permukiman dengan konsep utilitas terpadu.
\end{abstract}

Kata Kunci : Kawasan Pelabuhan, Ruang Publik, Permukiman Kumuh.

\section{PENDAHULUAN}

Salah satu kawasan pesisir pada teluk yang akan di kembangkan di wilayah Kabupaten Penajam Paser Utara adalah kawasan Pelabuhan sebagai pintu gerbang untuk masuk dan keluar dan Kabupaten Penajam Paser Utara memiliki nilai yang cukup strategis sehingga pengembangan dan pemanfaatan ruang kawasan tersebut harusnya memberi nilai lebih bagi masyarakat Kabupaten Penajam. Sebagai jalur lintasan trans Kalimantan, kawasan Pelabuhan Penajam memiliki peran penting dalam sirkulasi pergerakan penduduk dan barang baik antar kota dalam wilayah propinsi Kalimantan Timur atau antar kota yang memiliki kedekatan fisik wilayah, sehingga kawasan tersebut menjadi entri point bagi Kabupaten Penajam Paser Utara. Namun penataan kawasan ini belumlah optimal, hal ini dikarenakan keberadaan kawasan pemukiman atas air yang terkesan kumuh dan tidak sehat. Permasalahan lain adalah kurangnya ruang publik di Penajam juga menjadi salahsatu masalah tersendiri. Selain itu, masyarakat Penajam tidak memiliki orientasi yang jelas juga tidak mengenali identitas yang jelas terhadap suatu tempat dan keselarasan hubungan dengan tempat- tempat lain di Kota Penajam. Karenanya perlu adanya pendekatan perencanaan kawasan pesisir atau tepian air yang arah dan tujuannya untuk menata kembali pemanfaatan ruang pada lokasi yang dimaksud diatas dengan menitikberatkan pada pendekatan konsep perencanaan u ntuk tujuan pengalokasian ruang publik juga berfungsi sebagai entitas dan kota Penajam sebagai Ibukota Kabupaten Penajam Paser Utara. 


\section{STUDI KEPUSTAKAAN}

Wilayah Pesisir

Wilayah pesisir adalah daerah pertemuan antara darat dan laut. Ke arah darat wilayah pesisir meliputi bagian daratan, baik kering maupun terendam air, yang masih dipengaruhi oleh sifat-sifat laut, seperti pasang surut, angin laut dan perembesan air asin. Sedangkan ke arah laut, wilayah pesisir mencakup bagian laut yang masih dipengaruhi oleh proses alami yang terjadi di darat, seperti sedimentasi dan aliran air tawar maupun yang disebabkan karena kegiatan manusia di darat seperti penggundulan hutan dan pencemaran.

\section{Waterfront Development}

Wrenn (1983) mendefinisikan waterfront development sebagai "interface between land and water". Di sini kata "Interface" mengandung pengertian adanya kegiatan aktif yang memanfaatkan pertemuan antara daratan dan perairan. Adanya kegiatan inilah yang membedakannya dengan kawasan lain yang tidak dapat disebut sebagai waterfront development - meski memiliki unsur air - apabila unsur airnya dibiarkan pasif. Dengan demikian pengertian waterfront development dapat dirumuskan sebagai pengolahan kawasan tepian air yaitu kawasan pertemuan antara daratan dan perairan dengan memberikan muatan kegiatan aktif pada pertemuan tersebut. Perairan yang dimaksud bisa berupa unsur air alami (laut, sungai, kanal, danau) atau unsur air buatan (kolam, danau buatan). Sedangkan muatan kegiatan bisa berupa aktivitas perairan seperti berperahu (dayung atau layar) atau aktivitas pantai (pesisir, promenade, atau esplanade) yang memanfaatkan pemandangan perairan.

\section{Elemen Kota}

Secara garis besar Prof.Kevin Lynch menemukan dan mengumpulkan ada lima elemen pokok atau dasar yang oleh orang digunakan untuk membangun gambaran mental mereka terhadap sebuah kota, adalah sebagai Pathways, Edges, District, Nodes dan Landmark

Pelabuhan

Pelabuhan merupakan bandar yang dilengkapi dengan bangunan-bangunan untuk pelayanan muatan dan penumpang seperti dermaga, tambatan, dengan segala. perlengkapannya.

Public space

Public Space merupakan ruang yang selalu kita alami dalam kehidupan sehari-hari.. Berdasarkan etimologi, public space terdiri dan dua kata : public dan space. Kata public berasal dan bahasa latin populus yang berarti people atau orang. Pada Webster's Universal Dictionaty and Thesaurus, public adalah adjective for people in general (orang secara umum), performed in the front of people, for the use of all people, open or knwon to all, etc.

\section{RTH dan RTNH}

Ruang Terbuka Hijau (RTH), adalah area memanjang/jalur dan atau mengelompok, yang penggunaannya lebih bersifat terbuka, tempat tumbuh tanaman, baik yang tumbuh tanaman secara alamiah maupun yang sengaja ditanam. 
Ruang Terbuka Non Hijau(RTNH) ruang yang secara fisik bukan berbentuk bangunan gedung dan tidak dominan ditumbuhi tanaman ataupun permukaan berpori, dapat berupa perkerasan, badan air ataupun kondisi tertentu lainnya (misalnya badan lumpur, pasir, gurun, cadas, kapur, dan lain sebagainya). Tipologinya antara lain plaza, lapangan olahraga, tempat parkir, taman bermain, koridor, dan buffer.

\section{Identifikasi Permukiman Kumuh}

Untuk menetapkan lokasi kawasan permukiman kumuh digunakan kriteriakriteriayangdikelompok kedalam kriteria: (1) vitalitas non ekonomi; (2) vitalitas ekonomi kawasan; (3) kepemilikan tanah; (4) keadaan prasarana dan sarana; (5) komitmen pemerintah kabupaten/kota; (6) prioritas penanganan

\section{METODOLOGI}

Jenis studi ini adalah deskriptif evaluatif, yaitu perencanaan yang diawali dengan penelitian deskriptif. Penelitian deskriptif dapat $d$ iartikan sebagai proses pemecahan masalah yang diselidiki dengan menggambarkan keadaan subyek dan obyek penelitian pada saat sekarang berdasarkan fakta-fakta yang nampak atau kondisi eksisting. Pelaksanaan metode penelitian deskriptif tidak terbatas sampai pada pengumpulan dan penyusunan data, tetapi meliputi analisis dan interpretasi tentang data tersebut. Kemudian setelah data telah diolah dan dianalisis, maka disini proses evaluatif dilakukan dengan output sebuah konsep perencanaan.

\section{ANALISIS DAN PEMBAHASAN}

\section{Gambaran Umum}

Lokasi objek perencanaan berada di Kabupaten Penajam Paser Utara, KalTim, tepatnya di kawasan sekitar pelabuhan Fery, atau di RT 7,8, 9 dan RT 10 Kelurahan Penajam. Pada lokasi, terdapat kawasan permukiman yang terbentuk dan berkembang sejak lama dan terkesan kumuh. Karakteristik terbentuknya permukiman kumuh tersebut dapat dipengaruhi oleh adanya pusat aktivitas berupa kegiatan pelabuhan fery dan juga letaknya di daerah pantai juga merupakan permukiman diatas air atau dalam wilayah area pasang surut sehingga dapat dikategorikan sebagai kawasan kumuh area pasang surut dan permukiman kumuh dekat dengan pusat kegiatan ekonomi.

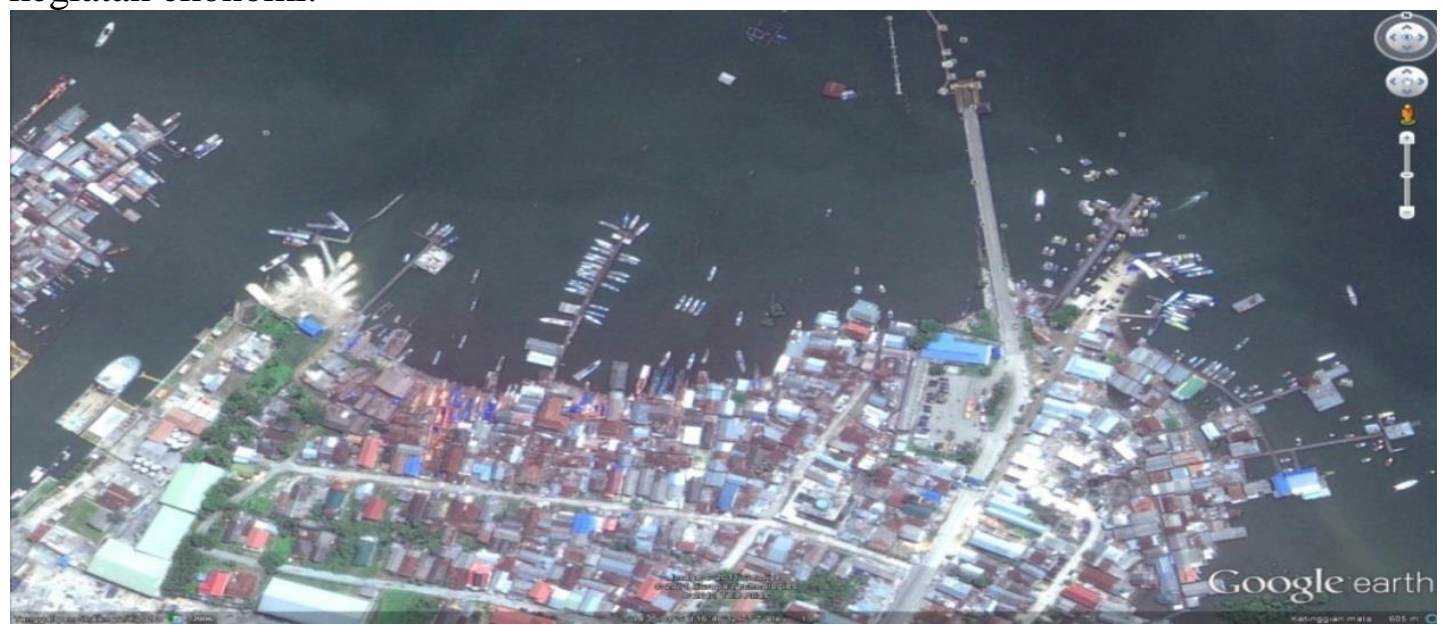

Gambar 1. Lokasi Perencanaan (sumber: google earth) 
Tinjauan jumlah penduduk kawasan pelabuhan (RT 7,8,9 dan RT 10) Kota Penajam akan digunakan sebagai acuan dalam menyusun penataan Data jumlah warga atau penduduk tersebut.

Tabel 1. Jumlah Penduduk Pada Lokasi Objek Perencanaan Tahun 2015

\begin{tabular}{|c|c|c|c|c|}
\hline No. & RT & Penduduk (Jiwa) & KepaIa KeIuarga (KK) & Keterangan \\
\hline 1 & 6 & 491 & 125 & \multirow{2}{*}{ Lokasi } \\
\hline 2 & 7 & 363 & 104 & \\
\hline 3 & 8 & 501 & 135 & \\
\hline 4 & 9 & 564 & 197 & \\
\hline 5 & 10 & 817 & 151 & \\
\hline 6 & 11 & 556 & 161 & \\
\hline 7 & 12 & 539 & 118 & \\
\hline 8 & 13 & 422 & 1.147 & \\
\hline \multicolumn{2}{|c|}{ Jumlah } & 4.253 & & \\
\hline
\end{tabular}

Sumber: Kantor Kelurahan Penajam

\section{Analisis Karakteristik Pantai Kota Penajam}

Pantai Penajam tergolong pantai tipe B digolongkan pantai yang berupa teluk tanpa pulau terletak di mulut teluk, kemiringan dasar yang landai $(0,01<\mathrm{s} 0,1)$ dan terbentuk dan pasir, memiliki lingkungan muara, tinggi ombak datang antara 1-2 meter, kecepatan arus antara 0,5-1 meter/detik, tipe pasut adalah campuran dan perioda ulang kejadiaan badai di atas 15 tahun.Pantai tipe B cukup potensial dikembangkan menjadi kawasan perdagangan dan prasarana penunjang pantai tipe A, namun perlu dilakukan rekayasa khusus untuk meningkatkan aksesibilitas terhadap pusat kota misalnya pembuatan dermaga, rekiamasi pantai dan sebagainya. Bentuk permukaan lahan yang datar dengan kemiringan 0 - 2\% cukup ideal untuk pengembangan kawasan pelabuhan dan fungsi-fungsi lainnya termasuk permukiman. Temperatur udara rata-rata sebesar $26^{\circ} \mathrm{C}$ dengan perbedaan temperatur pada waktu siang dan malam berkisar antara $5-7^{\circ} \mathrm{C}$. Temperatur minimum terjadi antara bulan Oktober sampai bulan Januari, sedangkan temperatur maksimum terjadi antara bulan Juli sampai bulan Agustus. Berdasarkan pembagian iklim di wilayah Kalimantan Timur, sebagian besar iklim Kabupaten Penajam Paser Utara termasuk Zona 1 dengan rata-rata curah hujan berkisar antara 2000-2500 mm per tahun.

\section{Analisis Kebutuhan Ruang Publik}

Analisis Pengalokasian Ruang untuk RTH

Menurut Peraturan Menteri Pekerjaan Umum No.5 Tahun 2008, pengalokasian ruang terbuka hijau untuk skala RW dengan jumlah penduduk 2.500 jiwa adalah $1.250 \mathrm{~m} 2$ dengan luas minimal perkapita adalah $0,5 \mathrm{~m} 2$.

Standar alokasi RTH skala RW per unit

Jumlah penduduk skala RW = Luas RTH Minimal Perkapita

$$
\frac{1.250 \mathrm{~m}^{2}}{2.500 \text { jiwa }}=0,5 \mathrm{~m}^{2} / \mathrm{jiwa}
$$


Artinya, alokasi atau lahan yang harus disediakan peruntukan RTH pada lokasi perencanaan adalah:

Jumlah penduduk pada lokasi perencanaan $\mathrm{x}$ Luas RTH minimal perkapita $=$ Alokasi
RTH 4.253jiwa $\times 0,5 \mathrm{~m}^{2} /$ jiwa $=2.126,5 \mathrm{~m}^{2}$

\section{Analisis Pengalokasian Ruang untuk RTNH}

Lokasi objek perencanaan merupakan pusat kegiatan yang terletak di Ibu Kota Kecamatan, sehingga pengalokasian Ruang terbuka Non Hijau menyesuaikan hierarki wilayah pada skala kecamatan atau kota dengan skala sedang dengan estimasi standar untuk kecamatan adalah 120.000 jiwa, dan kota sedang 100.000 hingga 500.000 jiwa.

Tabel 2. Perencanaan pengalokasian ruang RTNH pada lokasi

\begin{tabular}{|c|c|c|c|c|c|}
\hline PLASA & PARKIR & $\begin{array}{c}\text { LAP. } \\
\text { OLAHRAGA }\end{array}$ & $\begin{array}{l}\text { TAMAN } \\
\text { BERMAIN }\end{array}$ & BUFFER & KORIDOR \\
\hline $\begin{array}{l}\text { Merupakan } \\
\text { alun-alun } \\
\text { yang dapat } \\
\text { dimanfaatkan } \\
\text { untuk } \\
\text { beberapa } \\
\text { aktifitas } \\
\text { (aktifitas } \\
\text { berolahraga, } \\
\text { bersosialisasi, } \\
\text { dan bermain) } \\
\text { Luas minimal } \\
\text { 24.000 m² } \\
\text { berada pada } \\
\text { pusat } \\
\text { lingkungan } \\
\text { kecamatan. } \\
\text { Fungsi utama } \\
\text { sebagai ruang } \\
\text { aktifitas sosial } \\
\text { masyarakat } \\
\text { Fungsi } \\
\text { tambahan } \\
\text { yaitu fungsi } \\
\text { ekonomi } \\
\text { seperti acara } \\
\text { bazaar, } \\
\text { penggalangan } \\
\text { dana, dan } \\
\text { acara musik), } \\
\text { fungsi ekologis } \\
\text { (community } \\
\text { garde dalam } \\
\text { pot/bak), } \\
\text { fungsi } \\
\text { arsitektural }\end{array}$ & $\begin{array}{l}\text { Luas } 4.000 \mathrm{~m}^{2} \\
\text { di pusat } \\
\text { lingkungan } \\
\text { kecamatan } \\
\text { Dipisahkan } \\
\text { dengan } \\
\text { terminal } \\
\text { kecamatan } \\
\text { seluas 2.000 } \\
\text { m }^{2} \text { dan } \\
\text { pangkalan } \\
\text { oplet/ angkot } \\
\text { seluas 500 m² } \\
\text { Fungsi utama } \\
\text { sebagai lahan } \\
\text { parkir } \\
\text { komunal } \\
\text { lingkungan } \\
\text { kecamatan, } \\
\text { juga sekaligus } \\
\text { berfungsi } \\
\text { sebagai } \\
\text { pangkalan } \\
\text { sementara } \\
\text { kendaraan } \\
\text { angkutan } \\
\text { publik } \\
\text { Fungsi } \\
\text { tambahan } \\
\text { antara lain } \\
\text { fungsi sosial } \\
\text { budaya } \\
\text { (aktifitas } \\
\text { massal pada } \\
\text { saat-saat } \\
\text { tertentu), } \\
\text { fungsi }\end{array}$ & $\begin{array}{l}\text { Memiliki luas } \\
\text { minimal } \\
24.000 \mathrm{~m}^{2} \\
\text { Olahraga } \\
\text { yang dapat } \\
\text { diakomodasi } \\
\text { pada area } \\
\text { RTNH yaitu } \\
\text { bulutangkis, } \\
\text { voli, basket } \\
\text { atau senam. } \\
\text { Aktifitas } \\
\text { olahraga } \\
\text { lainnya yaitu } \\
\text { jogging track, } \\
\text { tenis, futsal } \\
\text { atau beladiri } \\
\text { Fungsi utama } \\
\text { sebagai sarana } \\
\text { olahraga } \\
\text { masyarakat } \\
\text { yang dapat } \\
\text { digolongkan } \\
\text { sebagai } \\
\text { aktifitas sosial } \\
\text { masyarakat. } \\
\text { Fungsi } \\
\text { tambahan } \\
\text { yaitu fungsi } \\
\text { ekonomi } \\
\text { seperti acara } \\
\text { bazaar, } \\
\text { penggalangan } \\
\text { dana, dan } \\
\text { acara musik), } \\
\text { fungsi } \\
\text { ekologis }\end{array}$ & $\begin{array}{l}\text { Memiliki luas } \\
\text { minimal } \\
24.000 \mathrm{~m}^{2} \\
\text { Area plasa } \\
\text { perlu } \\
\text { dilengkapi } \\
\text { dengan } \\
\text { beberapa } \\
\text { bentuk } \\
\text { peralatan } \\
\text { bermain } \\
\text { sederhana, } \\
\text { seperti } \\
\text { ayunan, } \\
\text { perosotan, } \\
\text { labirin mini, } \\
\text { dan lain-lain. } \\
\text { Fungsi utama } \\
\text { sebagai sarana } \\
\text { bermain } \\
\text { masyarakat } \\
\text { terutama } \\
\text { anak-anak } \\
\text { yang dapat } \\
\text { digolongkan } \\
\text { sebagai } \\
\text { aktifitas sosial } \\
\text { masyarakat. } \\
\text { Fungsi } \\
\text { tambahan } \\
\text { yaitu fungsi } \\
\text { ekonomi } \\
\text { seperti acara } \\
\text { bazaar, } \\
\text { penggalangan } \\
\text { dana, dan } \\
\text { acara musik), }\end{array}$ & $\begin{array}{l}\text { Pembatas } \\
\text { untuk skala } \\
\text { kecamatan } \\
\text { dengan luasan } \\
\text { dan } \\
\text { peletaakan, } \\
\text { disesuaikan } \\
\text { dengan sistem } \\
\text { lingkungan } \\
\text { tertentu. } \\
\text { Pembatas } \\
\text { antara satu } \\
\text { fungsi dengan } \\
\text { fungsi lainnya, } \\
\text { dengan luasan } \\
\text { dan peletakan } \\
\text { disesuaikan } \\
\text { dengan sistem } \\
\text { lingkungan } \\
\text { tertentu. } \\
\text { Fungsi utama } \\
\text { sebagai bentuk } \\
\text { pemisah antar } \\
\text { fungsi. } \\
\text { Fungsi } \\
\text { tambahan } \\
\text { yaitu fungsi } \\
\text { ekonomi } \\
\text { (dimanfaatkan } \\
\text { untuk } \\
\text { reklame), } \\
\text { fungsi } \\
\text { ekologis } \\
\text { (menanam } \\
\text { vegetasi } \\
\text { tertentu dalam } \\
\text { pot/bak), }\end{array}$ & $\begin{array}{l}\text { Koridor pada } \\
\text { skala } \\
\text { kecamatan } \\
\text { dapat berupa } \\
\text { jalur sirkulasi } \\
\text { antar } \\
\text { bangunan, } \\
\text { dengan luasan } \\
\text { dan peletakan } \\
\text { disesuaikan } \\
\text { dengan sistem } \\
\text { lingkungan } \\
\text { tertentu. } \\
\text { Dapat juga } \\
\text { berupa jalur } \\
\text { sirkulasi antar } \\
\text { satu fungsi } \\
\text { dengan fungsi } \\
\text { lainnya, } \\
\text { dengan luasan } \\
\text { dan peletakan } \\
\text { disesuaikan } \\
\text { dengan } \\
\text { kebutuhannya. } \\
\text { Fungsi utama } \\
\text { sebagai jalur } \\
\text { sirkulasi yang } \\
\text { dapat } \\
\text { dikategorikan } \\
\text { sebagai fungsi } \\
\text { sosial } \\
\text { Fungsi } \\
\text { tambahan } \\
\text { yaitu ekonomi } \\
\text { (dimanfaatkan } \\
\text { untuk } \\
\text { reklame), }\end{array}$ \\
\hline
\end{tabular}




\begin{tabular}{|c|c|c|c|c|c|}
\hline $\begin{array}{l}\text { (melengkapny } \\
\text { a dengan } \\
\text { ornamen } \\
\text { tertentu) }\end{array}$ & $\begin{array}{l}\text { ekologis } \\
\text { (melengkapiny } \\
\text { a dengan } \\
\text { vegetasi } \\
\text { tertentu), } \\
\text { fungsi } \\
\text { arsitektural } \\
\text { (melengkapiny } \\
\text { a dengan } \\
\text { ornamen } \\
\text { fungsional dan } \\
\text { estetis). }\end{array}$ & $\begin{array}{l}\text { (community } \\
\text { garde dalam } \\
\text { pot/bak), } \\
\text { fungsi } \\
\text { arsitektural } \\
\text { (melengkapny } \\
\text { a dengan } \\
\text { ornamen } \\
\text { tertentu) }\end{array}$ & $\begin{array}{l}\text { fungsi } \\
\text { ekologis } \\
\text { (community } \\
\text { garde dalam } \\
\text { pot/bak), } \\
\text { fungsi } \\
\text { arsitektural } \\
\text { (melengkapny } \\
\text { a dengan } \\
\text { ornamen } \\
\text { tertentu) }\end{array}$ & $\begin{array}{l}\text { fungsi } \\
\text { arsitektural } \\
\text { (melengkapiny } \\
\text { a dengan } \\
\text { ornamen } \\
\text { tertentu) }\end{array}$ & $\begin{array}{l}\text { fungsi } \\
\text { ekologis } \\
\text { (menanam } \\
\text { vegetasi } \\
\text { tertentu dalam } \\
\text { pot/bak), } \\
\text { fungsi } \\
\text { arsitektural } \\
\text { (melengkapiny } \\
\text { a dengan } \\
\text { ornamen } \\
\text { tertentu). }\end{array}$ \\
\hline
\end{tabular}

\section{Analisis Citra Kawasan Pelabuhan Kota Penajam}

Analisis yang dilakukan berupa pengolahan data-data primer hasil observasi lapangan dan mendominasi data-data primer yang bersumber dan hasil wawancara atau interview, hal ini terjadi karena indikator-indikator yang digunakan pada tiap tinjauan analisis berorientasi pada persepsi subjektivitas masyarakat.

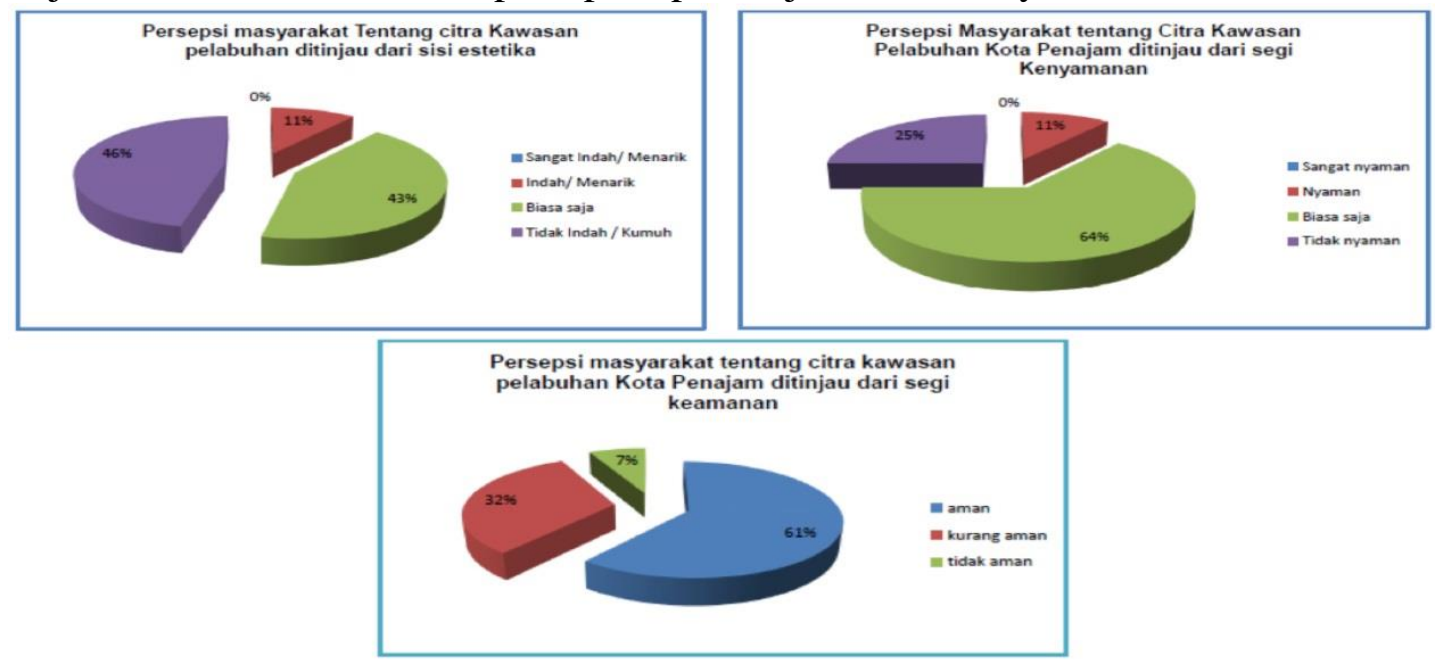

Gambar 2. Diagram Pie Hasil Analisis Citra Kawasan

\section{Analisis Kelayakan Pelabuhan kota Penajam}

1) Kesesuaian Kedalaman Laut dan Gelombang dengan Jenis Pelabuhan

Lokasi objek perencanaan, dalam hal ini kawasan pelabuhan Kota penajam, berada dalam kawasan Teluk Balikpapan sehingga terlindung dan gelombang laut yang sangat besar. Kedalaman laut pada kawasan perairan lokasi perencanaan relatif cukup, yaitu berkisar antara 0-5 meter pada musim kemarau dan pada musim penghujan bisa mencapai 2,5 meter. Beda permukaan air antara musim penghujan, dengan curah hujan 2000-2500 mm per tahun dapat mencapai 0,5-2 meter. Perlu diketahui, bahwa beda permukaan air pada musim kemarau dan musim penghujan bisa mencapai 8 meter untuk kawasan yang memiliki curah hujan tinggi.

2) Kesesuaian Daya Tampung dan Layanan Terhadap Kebutuhan dan Jumlah Penumpang

Dermaga pada pelabuhan ferry ini hanya mampu ditambatkan oleh satu kapal saja. Sedangkan jumlah penumpang menurut statistik pada tahun 2009, kendaraan yang menggunakan jasa penyebrangan ferry ini terdapat 274.791 kendaraan yang datang dan 270.312 kendaraan yang tiba di pelabuhan untuk segala tipe kendaraan, artinya terdapat sekitar 1,514 kendaraan yang menggunakan jasa penyebrangan ferry 
ini rata-rata tiap harmnya. Banyaknya jumlah kendaraan yang menggunakan jasa penyebrangan ferry ini, dan tidak terakomodasinya kendaraan-kendaraan tersebut dikarenakan dimensi dermaga yang hanya mampu ditambatkan oleh satu kapal, membuat para penumpang dan pengendara harus menunggu dan antri berjam-jam agar dapat masuk ke kapal. Karenanya perlu dilakukan penambahan dimensi ataupun jumlah dermaga sehingga dapat melayani kebutuhan pelanggan atau pengguna jasa penyebrangan ini dengan baik.

3) Kesesuaian Jenis dan Jumlah Kapal Terhadap Dimensi Dermaga

Untuk dermaga yang melayani atau menjadi tambatan untuk satu kapal jenis ferry dengan bobot (GRT) 1.000-3.000 dengan draft 3,7-4,3 meter dan panjang 73-90 meter, sebenarnya dermaga ini sudah tergolong mampu dan layak. Apalagi kedalaman kolam pada ujung dermaga mencapai 12 meter. Artinya, kondisi dermaga dikategorikan mampu dan layak untuk jenis kapal tersebut.

4) Kelengkapan Fasilitas Pelabuhan

Kelengkapan dan fasilitas pada pelabuhan ini tergolong memadai. Mulai dari terminal penumpang berupa bangunan yang berfungsi sebagai kantor dan ruang tunggu, loket pembelian karcis, dermaga serta pemecah gelombang dan tempat parkir. Selain itu, fasilitas-fasilitas lain seperti tempat sampah, penerangan, hingga kafetaria juga tersedia pada pelabuhan ini. Untuk tempat parkir, meskipun telah disediakan, namun tidak mampu mewadahi semua kendaraan yang ingin menggunakan jasa penyebrangan ferryini.

5) Dermaga Speed Boat dan Kelotok

Dermaga speed boat pada lokasi objek perencanaan berbentuk jembatan dan memiliki panjang 60 meter dengan material kayu. Diatasnya terdapat dua bangunan yang difungsikan sebagai loket karcis, ruang tunggu dan toilet umum. Salah satu sisi dermaga jembatan ini terdapat dermaga apung yang tersambung dengan dermaga utama sebagai tambahan agar daya tampung dermaga mampu mewadahi semua speed boat yang beroperasi. Permasalahan pada dermaga ini adalah letaknya yang terlalu berdekatan dengan dermaga kelotok, sehingga sirkulasi dan pergerakan kedua jenis transportasi air tersebut cukup saling mengganggu. Selain itu dimensi dermaga speed boatini belum mampu melayani semua speed boat meskipun telah ditambahkan dermaga apung pada sisi kirl dermaga utama.

6) Identifikasi Permukiman Kumuh

Identifikasi permukiman pada lokasi perencanaan akan menilai tingkat kekumuhan yang kemudian akan memberikanjawaban seperlunya mengenai penataan permukiman kriteria kawasan permukiman kumuh yang telah dipaparkan pada poin landasan teori. Adapun kesimpulan identifikasi dan beberapa kriteria yang telah dianalisis adalah sebagai berikut.

Tabel 3. Bobot identifikasi permukiman kumuh pada lokasi perencanaan

\begin{tabular}{|c|l|l|}
\hline No. & Uraian & Bobot \\
\hline 1 & Aspek kesesuaian pemanfaatan ruang kawasan dalam rencana tata ruang kota & 30 \\
\hline 2 & Pertumbuhan bangunan liar & 30 \\
\hline 3 & Kepadatan bangunan & 50 \\
\hline 4 & Kondisi bangunan temporer & 30 \\
\hline 5 & Tapak bangunan & 50 \\
\hline 6 & Jarak antar bangunan & 50 \\
\hline 7 & Tingkat kepadatan penduduk & 50 \\
\hline 8 & Tingkat pertumbuhan penduduk & 50 \\
\hline 9 & Tingkat kepentingan kawasan dalam letak dan kedudukannya pada wilayah kota & 50 \\
\hline
\end{tabular}




\begin{tabular}{|l|l|l|}
\hline 10 & $\begin{array}{l}\text { Jarak jangkau kawasan terhadap tempat mata pencaharian penduduk kawasan } \\
\text { permukiman }\end{array}$ & 50 \\
\hline 11 & Status pemilikan lahan & 20 \\
\hline 12 & Status sertifikat tanah & 50 \\
\hline 13 & Kondisi alan & 30 \\
\hline 14 & Kondisi drainase & 50 \\
\hline 15 & Kondisi air bersih & 20 \\
\hline 16 & Kondisi Air Iimbah & 50 \\
\hline 17 & Kondisi persampahan & 50 \\
\hline 18 & Komitmen pemda dalam bidang pembiayaan & 50 \\
\hline 19 & Komitmen pemda dalam bidang kelembagaan & 20 \\
\hline 20 & Komitmen pemda dalam bidang rencana penanganan & 30 \\
\hline 21 & Komitmen pemda dalam bidang pembenahan fisik & 50 \\
\hline 22 & Komitmen pemda dalam bidang penanganan kawasan & 30 \\
\hline \multicolumn{2}{|l}{ Jumlah } & $\mathbf{8 9 0}$ \\
\hline
\end{tabular}

\section{KESIMPULAN}

Perencanaan Dermaga, Kolam pelabuhan dan Pemecah Gelombang

Perencanaan pelebaran dimensi jembatan selebar 20 meter, dibuat dengan dua jalur yang dipisahkan dengan jalur hijau sekaligus berlungsi sebagai penerangan. Selain itu juga direncanakan jalur khusus untuk roda dua selebar 1,5 meter dan trotoar selebar 1 meter. Antara trotoar dan lajur untuk kendaraan dipisahkan dengan pembatas railing besi setinggi 1 meter, hal ini direncanakan guna untuk keselamatan pejalan kaki yang akan menggunakan jasa penyeberangan ferry, meskipun juga akan direncanakan fasilitas mini bus untuk mengangkut penumpang tanpa kendaraan dan terminal keberangkatan menuju kapal ferry. Panjang eksisting dan jembatan/ dermaga ini adalah 125 meter dan lebar dermaga untuk tambatan kapal berdasarkan hasil analisis kesesuaian jenis dan jumlah kapal terhadap dimensi dermaga adalah 54 meter. Diujung dermaga juga disediakan bangunan yang berfungsi sebagai persiapan penambatan kapal dan pengawasan. Perencanaan dermaga ini tentu saja juga dibarengi dengan penambahan dimensi kolam pelabuhan pula.

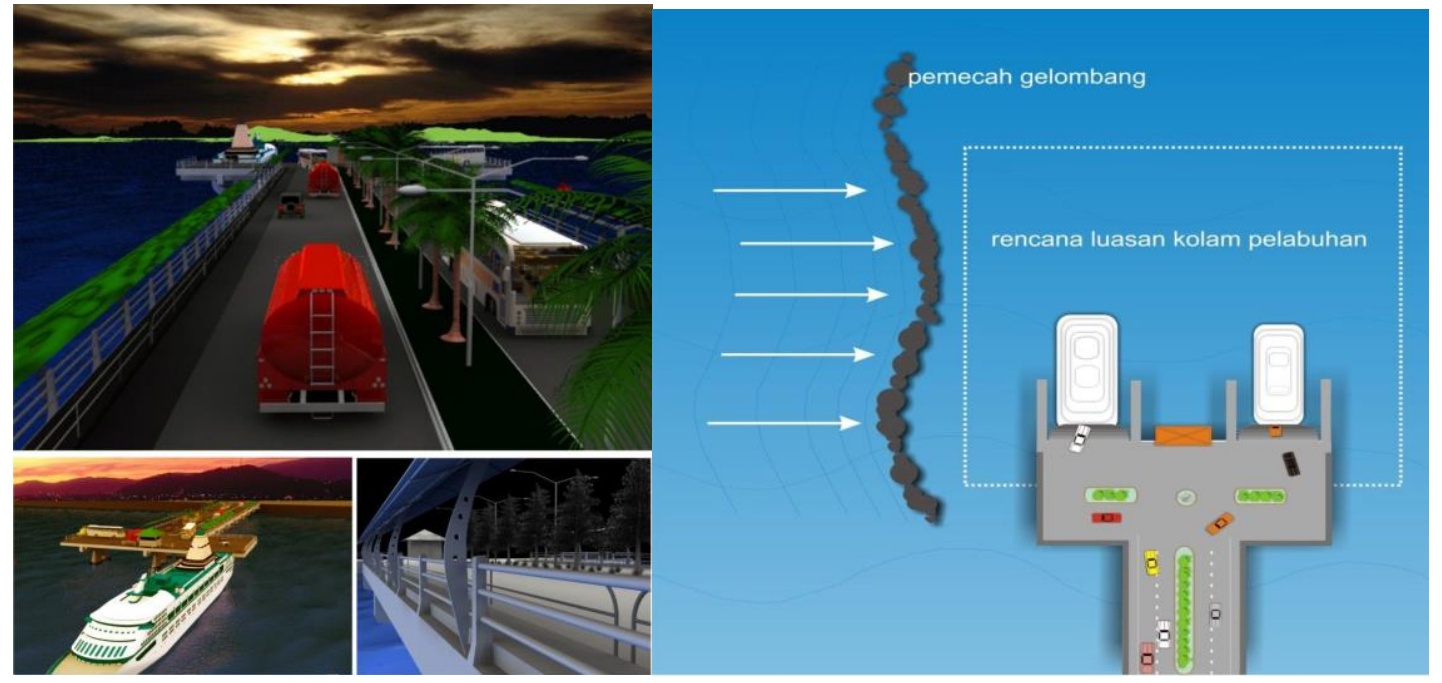

Gambar 3. Visualisasi Perencanaan Dermaga Kota Penajam

Perencanaan Fasilitas Pokok dan Fasilitas Penunjang Pelabuhan Ferry Penyeberangan 
1) Perencanaan Fasilitas Pokok:

a) Terminal penumpang untuk keperluan menunggu sebelum keberangkatan kapal, perpindahan antar moda transportasi perairan dengan angkutan jalan serta mengatur kedatangan dan keberangkatan kendaraan umum.

b) Penimbangan kendaraan bermuatan untuk mengendalikan kelebihan muatan serta untuk mengetahui besar muatan yang diangkut oleh ferry

c) Jalan penumpang keluar masuk kapal (gang way)

d) Perkantoran untuk kegiatan pemerintahan dan pelayanan jasa seperti loket penjualan tiket.

e) Fasilitas penyimpanan bahan bakar (bunker) untuk keperluan kapal ferry.

f) Instalasi air, listrik dan telekomunikasi.

g) Fasilitas pemadam kebakaran.

h) Tempat tunggu kendaraan bermotor sebelum naik ke kapal ferry

2) Perencanaan Fasilitas Penunjang :

a) Tempat pembuangan dan pengelolaan limbah

b) Fasilitas usaha yang menunjang kegiatan pelabuhan penyeberangan

c) Fasilitas umum lainnya seperti peribadatan, taman, jalur hijau, dan pos atau klinik kesehatan.

d) Fasilitas mini bus untuk penumpang yang akan menggunakan jasa ferry penyeberangan tanpa kendaraan

\section{Perencanaan Dermaga Speed Boat dan Kelotok}

Perencanaan dermaga speedboat dan kelotok dilakukan dengan tujuan peleyanan penyebrangan yang lebih baik dan tertata. Untuk dermaga speed boat, direncanakan penambahan dimensi panjang, hal ini dilakukan untuk menjaga jarak dengan pelabuhan kelotok yang terlalu dekat dan dapat mengganggu sirkulasi pelayaran untuk penyeberangan. Dermaga speed boat yang panjang awalnya 50 meter, direncanakan untuk ditambah menjadi 70 meter, dengan jorokan mengarah kearah timur laut. Selain itu direncanakan juga perluasan dimensi untuk mooring atau tempat bersandar dan menambatkan speedboat. Selain itu pada dermaga juga dilengkapi dengan bangunan yang berfungsi sebagai ruang tunggu, loket karcis, dan toiletumum.

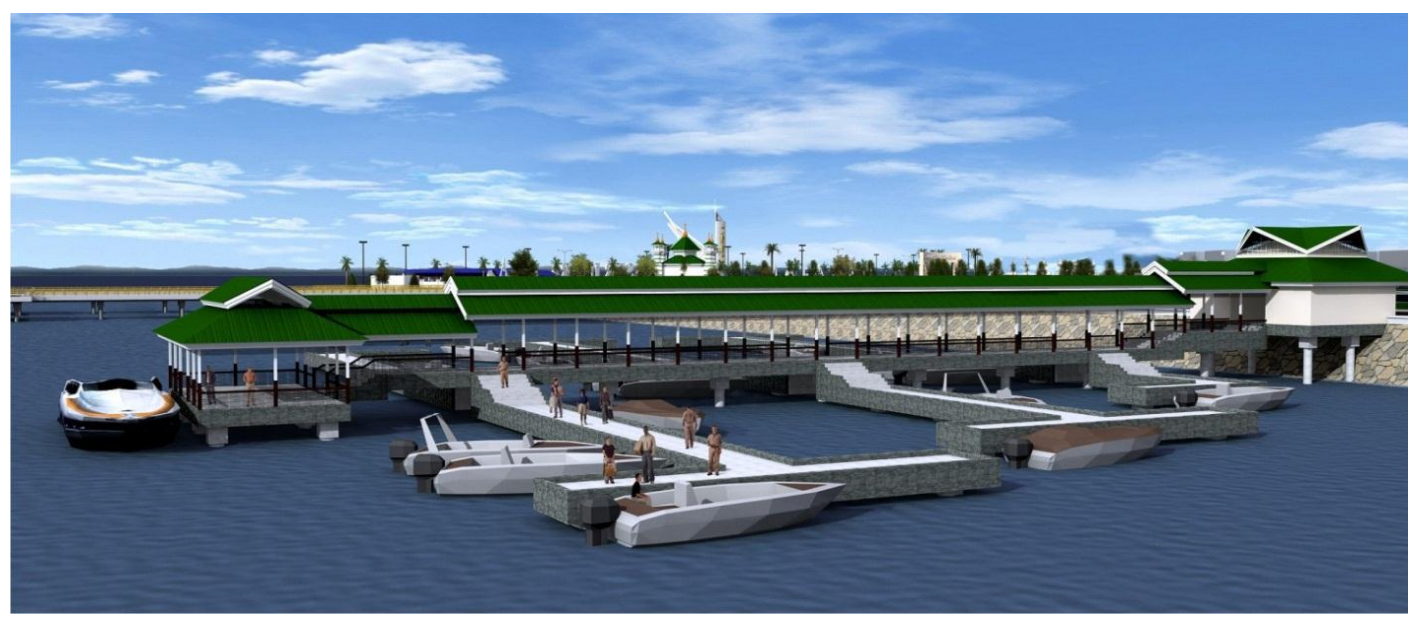

Gambar 4. Visualisasi Perencanaan Dermaga Speedboat

Perencanaan Landmark dan Ruang Terbuka Publik

1) Perencanaan vocal point dan centre building sebagai landmark kawasan. 
2) Perencanaan tempat parkir dan fasilitas tunggu kendaraaan pengguna ferry penyeberangan.

3) Perencanaan Buffer dan Dermaga Apung.

4) Perencanaan lapangan olahraga dan taman bermain.

5) Perencanaan Plaza.

6) Perencanaan hutan kota.

7) Perencanaan sculpture sebagai ciri khas kawasan

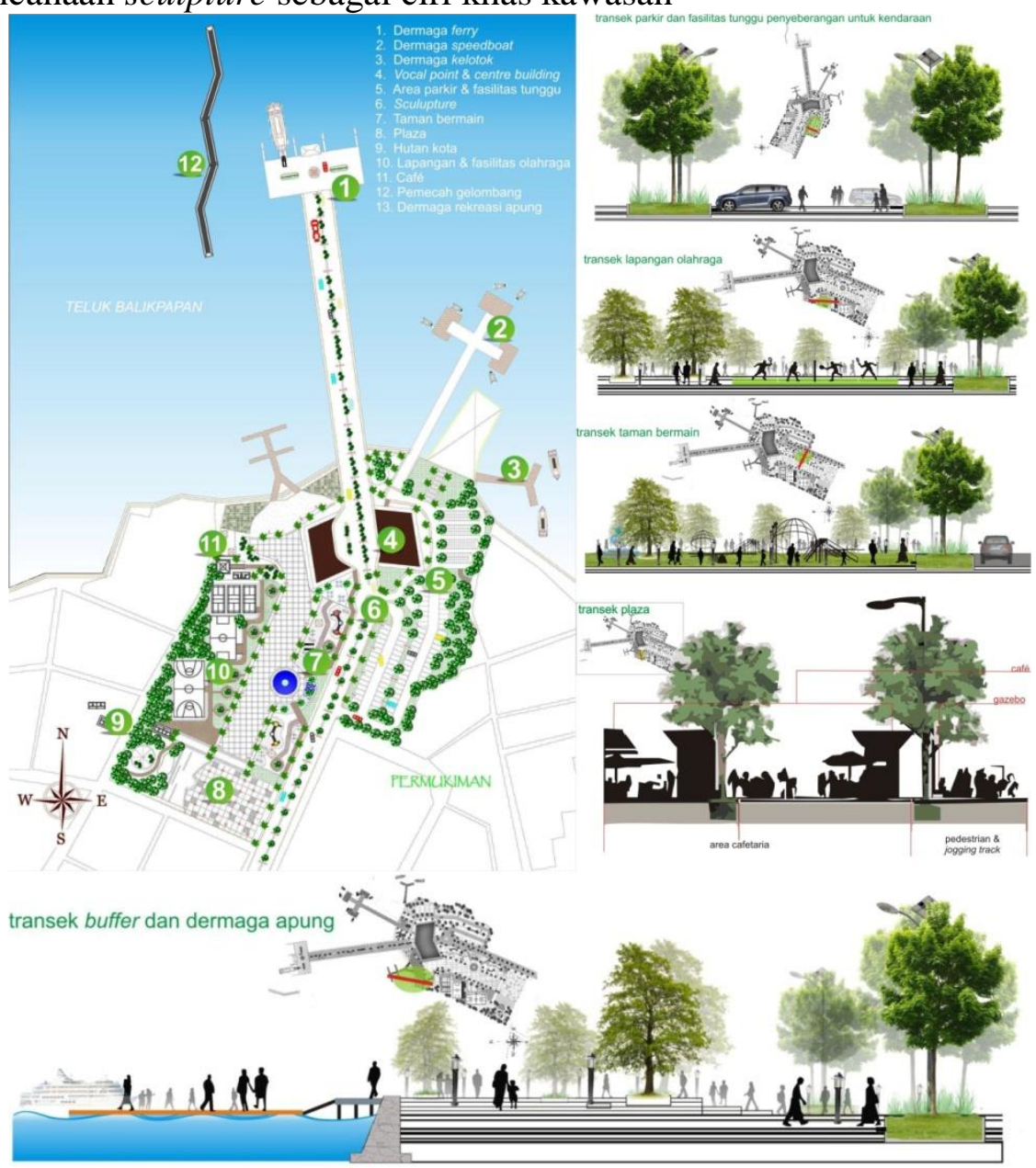

Gambar 5. Perencanaan Public Space

\section{Penataan Kawasan Permukiman Kumuh Dengan Konsep Utilitas Terpadu}

1) Optimalisasi Fungsi Lahan pada Permukiman

Meskipun angka pertumbuhan rumah-rumah baru pada permukiman ini tergolong sangat kecil, namun perlu dilakukan perencanaan untuk hal tersebut. Pembuatan atau penambahan bangunan baru untuk pertumbuhan permukiman ini secara fisik idealnya tidak dilakukan lagi. Kalaupun harus dilakukan, maka diarahkan pembangunan secara vertikal, karena pembangunan secara horizontal tak dapat dilakukan lagi karena keterbatasan lahan. Bangunan-bangunan atau rumah-rumah yang tua yang mulai lapuk khendaknya direnovasi hingga Iayak ditempati.

2) Sistem Pengolahan Air Limbah Bekas Pakai Rumah Tangga

Limbah air buangan bekas pakai rumah tangga dialirkan melalui dry swesle atau langsung menuju IPAL (instalasi pengelolaan air limbah). Proses penguraian air 
limbah atau zat pencemar, secara biologis akan menghasilkan efluen air limbah yang aman bagi perairan dengan efektifitas pengurangan zat pencemar hingga $90 \%$.

3) Sistem Pengelolaan Air Limbah Fases dengan Septictank

Perencanaan septictank yang dilakukan pada lokasi objek perencanaan adalah dengan perencanaan septictank modern atau septictank biologis yang dikelolasecara komunal. Septictank yang akan digunakan seperti halnya dengan septictank pada umumnya yaitu berupa bangunan tabung, hanya saja bagian dasarnya tertutup, sehingga air limbah tidak merembes ke dalam air. Sebenarnya ada berbagai macam alternatif sistem yang dapat dipergunakan dalam pengaplikasian septic tank ini, namun konsep septic tank komunal ini sangat efisien sehingga konsep komunal Iah yang terpilh untuk diaplikasikan dalam konsep perencanaan ini.
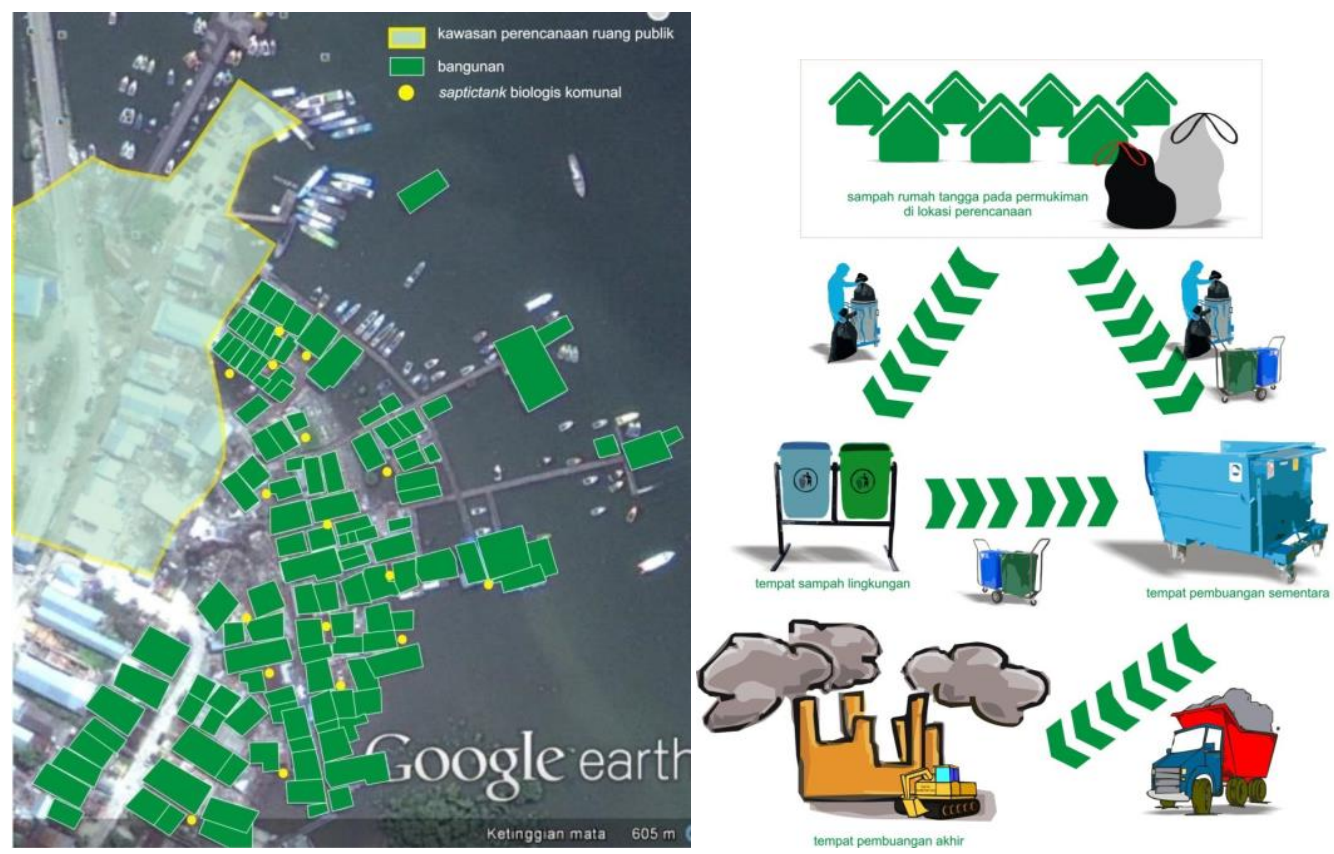

Gambar 6. Perencanaan Septictank Biologis Komunal dan System Persampahan pada Permukiman di Lokasi Perencanaan

4) Pengelolaan Sistem Persampahan

Sistem persampahan pada permukiman mi direncanakan dengan meletakkan tempat-tempat sampah untuk melayani sampah rumah tangga. Tempat sampah mi direncanakan mampu melayani 5-10 rumah dengan radius pelayanan 10-30 meter. Dan tempat sampah tersebut, kemudian diangkut dengan karung atau gerobak sampah ke tempat pembuangan sementara untuk skala Iingkungan kecil, yang dan sini diangkut oleh truk sampah ke tempat pembuangan akhir.

Kabupaten Bone tahun 2009 mencapai 711.748 jiwa, tersebar di 27 kecamatan dengan konsentrasi penduduk terbesar di Kecamatan Tanete Riattang,

\section{DAFTAR PUSTAKA}

Badan Pusat Statistik Kabupaten Penajam Paser Utara. 2009. Kecamatan Penajam Dalam Angka 2009.

Dahuri, Rokhmin dkk. 2008. Pengelolaan Sumber Daya Wllayah Pesisir dan Lautan Secara Terpadu. Pradnya Paramita; Jakarta. 
Darmawati. 1997. Perancangan Kawasan tepian Air (Studi Kawasan tepian Air di Negara Maju dan Pengembangan Tepian Air di Kotamadya Ujung Pandang). Skripsi Jurusan Arsitektur Fakultas Teknik Universitas Hasanuddin.

Pranita, Ian. 2010. Identifikasi Karakteristik Ruang Terbuka Hijau Di Kota-Kota Pantai Indonesia (Studi Kasus Kota Padang, Denpasar Dan Makassar) Departemen Arsitektur Lansekap Fakultas Pertanian Institut Pertanian Bogor.

PSDAL UNHAS dan Direktorat Bina Tata Perkotaan dan Pedesaan Departemen Pekerjaan Umum, (1997), Tipologi Pengembangan Kawasan Pesisir Pantai.

Rhomaidhi. 2008, Pengelolaan Sanitasi Secara Terpadu Sungai Widuri: Studi Kasus Kampung Nitiprayan Yogyakarta. Teknik Lingkungan Universitas Islam Indonesia.

Taringan, Robinson. 2006. Perencanaan Pembangunan Wilayah . Jakarta . Bumi Aksara.

Triatmodjo,Bambang, Dr.,lr.1992. Pelabuhan, bahan Kuliah Fakultas Teknik Universitas Gajah Gada.

Yunus, H. Sabari. 2000. Struktur Tata Ruang Kota. Yogyakarta. Pustaka Pelajar 